\title{
Strengthening Political Governance in the Extractive Industry: Panacea for Revenue Transparency and Development in Nigeria
}

\author{
Nnaa, Biiragbara Godpower (Ph.D) \\ Department of Business Administration and Management, Rivers State Polytechnic, Bori Nigeria \\ Kia, Bariledum (M.Sc, Ph.D in View) \\ Facilitator, National Open University of Nigeria, Port Harcourt Study Centre, Nigeria \\ Nwibor, Lucky Barika (B.Sc, PGD MA) \\ Director School of Foundation Studies, Rivers State Polytechnic, Bori Nigeria
}

Doi:10.5901/mjss.2015.v6n2s1p596

\begin{abstract}
This study examines the relationship between political governance and extractive industry performance in Nigeria. It tends to know the contributions of political governance structures in the Nigerian extractive economy sector and whether the political sector has been able to achieve effective regulatory framework leading to revenue transparency which is the key factor in the attainment of sustainable development. In carrying out this research we made use of secondary data, mostly, the relevant literatures on the subject matter. Descriptive analytical approach was employed, while structural functionalism approach was adopted as the framework of analysis. The study revealed among other things that weak political institutions to undertake effective checks and balances and the virtual absence of regulatory framework created opportunistic gaps for predatory elites to institutionalized corruption in the oil extractive industry. The end result is loss of revenue, deep poverty and poor standard of living. Based on this, the paper recommended amongst others, the development of effective framework for transparency and accountability through strengthening of political governance, effective implementations of the Nigerian Extractive Industry Transparency Initiative (NEITI) Act of 2007, and fundamental restructuring of the Nigerian political and administrative structure and socialization of the social mode of production.
\end{abstract}

Keywords: Political Governance, Extractive Industry, Revenue Transparency and Development

\section{Introduction}

The imperative for good governance in the extractive industry in Nigeria cannot be over-emphasized. This is because; Nigeria today depends on extractive industry for almost all her development processes. The fact that there is an intricate connection between governance and other socio-economic issues including economic growth, development, security and even democracy in Nigeria cannot be disputed. Good governance provides functional, purposeful, dynamic, responsive and visionary political leadership which has been found to be responsible for the steering of the desired progress and transformation in the best managed economic today (Hope 2002) ). Governance ultimately relates to the totality of the processes entailed in the exercise and management of the collective will of the people. Thus, state institutions like the legislator, the executive and the judiciary are expected to approach their responsibility in transparent and accountable manner that would guarantee peace and settle development. These institutions through their interrelated functions of the decision-making process, implementation and formulation of sound policies including the exercise of oversight functions, guide and direct the affairs of the nation, making government live up to its responsibility of providing the citizens with essential services. However, there is in recent time an increasing loss of confidence in the governance structure due to enormous problems confronting the people. That our country Nigeria is rich in extractive resources, especially crude oil and other mineral resources is a fact, yet, despite this abundant wealth in resources, it is also a fact that our people are generally poor, sick, hungry, poorly educated and exploited. And their condition worsened in this era of democracy. In the extractive industries, the nation and operators of these industries boast of hundred of millions of dollars, but the obvious question is "who benefits from all this billions of dollars? 
Mountains are leveled, forests are cut, rivers are polluted and farmlands poisoned whole villages are displaced, families are driven into sickness, livelihoods are lost and those opposed to ill practice of extractive industries are brutalized and skinned. No meaningful development takes place while foreign operators in the extractive industries and local corroborators of elite get richer in the end (a handful of people profit enormously) while those who work hardest remain struck in harsh, arduous and tedious foul and live in poisoned communities.

Nigeria is classified by the UN and other related international bodies as "less developed countries (LDC). Whichever yardstick is applied - income, mutation, access to health services, access to potable water, life expectancy, access to education, human physical security (Kawzy, 2001); Nigeria fair very poorly in relation to the rest of the world. This reality underscores the importance of strengthening political governance to realize the needs of society, the need to facilitate the creation of opportunities within which the citizens can identify, develop and use the resources necessary to build a peaceful, equitable and just society. Experience also shows that good political governance can be attained only if development strategies incorporated concern for extractive industries, impact on tension that could lead to violence and promote measures to counteract such tensions.

Unfortunately, the reverse is the case in Nigeria. Instead of political governance to focus on decreasing the key structural risk factors in extractive industries such as neglect of corporate social responsibilities, poor compliance to local content regulation, inadequate compensation practice, lack of revenue transparency, the governance structure institutionalized discrimination and other ill-practice especially corruption, to fuel violent conflict in the industrial sector.

The former Governor of Central Bank of Nigeria, Malam Sanusi L. Sanusi in his letter to Mr. President, indicated that there was a difference between the value of crude lifted by NNPC (US\$ 65 billion) between January2012 and July 2013 , and the amount repatriated to the Federation Account (US $\$ 50$ billion) was observed. Besides CBN, there were several allegations against the NNPC for non remittance of funds to the Federation Account. E.g. NEITI, KPMG and Nuhu Ribadu Committee, all made such allegations before. The problem of non-remittance of revenue by NNPC was not new and it was not the Central Bank of Nigeria (CBN) Governor that first disclosed it, it has been a recurring issue at monthly Federation Account Allocation Committee (FAAC) meetings sometimes leading to states commissioners of finance walking out of the meeting. Recomputed crude and refined oil loses for the period January 2012 to July 2013 was US $\$ 0.809$ billion, an increase of US\$ 0.05 billion from NNPC figure.(Tell Magazine August 2014)

The obvious question is why this situation, when state structures designed to ensure revenue transparency and accountability exist. Institutions such as Federal Ministry of Finance, Federal Inland Revenue Services, and the Auditor General of the Federation and the Central Bank of Nigeria are expected to work in interrelated manner to ensure revenue transparency. Yet, in the face of these institutions, non-remittance of proceeds to payment of subsidy on product that is not subsidized, and increase pipeline surveillance cost without corresponding decrease in pipeline oil losses are on the increase. Without overtaking the obvious, there is poor governance structure and weak institutions to check the uncoordinated activities among and between key institutional structures in the extractive industries.

Speaking on the nexus between political governance and extractive resources for development, the president of the African Development Bank (ADB) asserted that "good governance is not only a working goal but also a prerequisite for sustainable development and poverty reduction in the longer term (Kabbay, 2003). Institutions such as the panel of the wise (POW), New Partnership for African's Development (NEPAD) and African Peer Review Mechanism (APRM) amongst others have engaged in activities to support good governance on the continent, because, where good governance is under threat, development is also threatened, and situation where development is threaten, peace is not guarantee. When considering the nexus between extractive industries in Nigeria and the broader political environment, the need for greater peace and stability is apparent and a vital aspect in achieving this is the need to strengthen political governance structures; not only to assist in realizing improved stability and security, but in ensuring a meaningful and sustainable transparency in the extractive industries. Strengthening political governance to enhance development in Nigeria can therefore, be understood as the effective use of political authority in the management of natural resources for socio-economic development. This involves state institutions, decision-making processes, policy making information flows and the leadership responsible for allocating resources and power within the society.

Therefore, the paper seeks to discuss how to strengthen political governance to ensure proactive extractive industrial sector and development engineering in Nigeria. In this regard, the paper identified the following key objectives:

* To outline parameters for governance to ensure transparency and accountability in the extractive industrial sector

* To examine the implications of poor political governance on the performance of the extractive sector of the nation's economy.

* To identify and develop mechanisms for addressing governance challenges in Nigeria. 
To achieve the enduring significance of the subject under discussion, the paper is organized in threefold dimension; first, the paper conceptualizes the key word - governance, secondly, it discusses the challenges of political governance and finally, suggests the ways of enhancing political governance in Nigeria for better extractive resource management.

\section{Political Governance - Defined}

Governance is an integral aspect of every society. The concept of governance involves the exercise of authority and denotes the manner in which responsibility is discharged. Chibba (2009) simply defines governance as "all aspects of the way a nation is governed, including its institutions, politics, laws, regulations, processes and oversight mechanisms." In the context of this paper, the governance of public office tagged 'political governance' is prominent in the discussion of extractive industry, hence the use of the broader United Nations Development Programme (UNDP) definition, which sees governance as the "exercise of power or authority to manage a country's resources and affairs. It consists mechanisms, processes and institutions through which citizens and groups articulate their interests, exercise their rights and obligations, and mediate their differences (UNDP, 1997). Good governance emphasizes values such as participation, representation, accountability, transparency, responsiveness and respect for the rule of law. Good political governance requires fair, legal frameworks to be enforced by an impartial, independent judiciary. The judiciary's decisions should be transparent and implemented in a way that follows established rules and regulations. Transparency and the rule of law are required to hold leadership accountable, making accountability, a key requirement for good governance (Sharma, 2007).

\section{Challenges of Political Governance}

\subsection{Weak Institution}

In discussing governance challenges in Nigeria, most scholars often cite weak institutions as a fundamental reason for poor governance. Corroborating this assertion, Brautigam and Knack (2004) argued that colonial structures did very little to develop strong, indigenously rooted institutions that could tackle the development demands of modern states. While not dismissing this thought in its totality, it will be however, misleading to put the blame on faulty focus of colonialism in the $21^{\text {st }}$ century, given that poor leadership and weak institutions have also been a product of poor choices in PostIndependence Nigeria. In furtherance of their argument, Brautiyam and Knack (2004) sum up this situation that;

"when patterns of poor governance deeper over time and become institutionalized, the political difficulties of reform become even more challenging"

Weak or poor political governance finds its expression through the absence of the rule of law, limits to democracy, lack of accountability and transparency, and multifaceted corruption in the oil sector. Some scholars have argued that weak political governance in Nigeria emanate from incompetence, ignorance and democratic deficits. What is unique in the case of Nigeria, however, is that the scramble for wealth by ruling predator elites dominated the life of Nigeria, to the extent that lack of a regulatory framework continues to nurture corruption in the extractive industrial sector.

\subsection{The inability of the Political Structure or Institutions to undertake effective Checks and Balances}

The inability of the political structure or institutions to undertake effective checks and balances has created opportunistic gaps for predatory elites, as there is little possibility of accountability in the oil extractive industry. Today, large scale bribery is common in the extractive industry in Nigeria, as exemplified by the following case; in December 2010, the US Company, Halliburton paid a USD 35 million fine to settle a case with Nigerian authorities. The case relates to a join venture between KBR (a subsidiary of Hallibutorn until 2007), Snanprogettic Netherlands (a unit of Saipen SPA and subsidiary of Eni SPA of Italy), Technip of France and Japan's JGC officials were bribed USD 180 million over a 10 year period to win a 6 USD billion contract to build a liquefied gas plan. All were found guilty in US courts: KBR and Halliburton were fined USD 579 million in 2009, Saipen and Eni paid a settlement of USD 365 million and Tehnip reached a USD 342 million settlement. JGL was the last to settle their case, paying a USD 218.8 million fine in April, 2011 (US Department of Justice, 2011). 


\subsection{Corruption}

Corruption is responsible for the disappearance of oil revenues, while decades of environmental problems associated with the oil industry go unaddressed. Investment Climate Statement, 2013 reported that the theft of crude oil from pipeline is about 300,000 barrels per day.

Some observers affirm that schemes orchestrated by political elites make up the vast bulk of illicit oil exports in Nigeria. It is alleged that there has been massive corruption and misappropriation of funds from the oil industry by top politicians and officials within the Nigerian National Petroleum Corporation (NNPC). For instance, according to a February 2014 article by BBC News, the fourteen $\left(14^{\text {th }}\right)$ Nigeria's Central Bank governors, Lamido Sanusi, alleged that over $\$ 20$ billion of oil revenue were missing between January 2012 and July 2013, amounting to almost one third of revenues.

The politics in Nigeria is more of oil and gas resource management. With a barrel of oil per day currently selling at little above 100 USD per barrel, and the nation's daily production quota of over 2.5 million, Nigeria's per capita income, the standard of living of Nigerians should have significantly improved. But, the occurrences in the oil industry, a reflection of poor political governance, which tends to distribute resources in a lopsided manner and created youth unemployment, and poor infrastructural facilities. The devoid of the necessary checks and self-institutional assessments have often become machinery that benefits only the ruling elite, at the expense of the greater citizenry (USAID, 2006).

\subsection{Lack of Culture of Transparency}

The failure to institutionalize a culture of transparency that calls for constant assessment and which interrogates the benefit of particular decisions for the greater/effective extractive resources management is a significant challenge that continues to undermine sustainable development in Nigeria. In Nigeria, youth unemployment levels are among the highest in the world at approximately $60 \%$ of young people. The unfortunate thing is that youth unemployment occasioned by malfunctioning institutions poses threat to durable peace and have serve as criminal and conflict drivers. Many of the Nigerian youths who are unemployed and uninvolved in socio-political processes find way to vent their frustration and express their marginalization. The rise of protest politics among disenchanted youths is very common today. A recent study by Nnaa and Kia (2013) and Nnaa (2011) corroborates this assertion. According to them, the collapsed nature of African States and patterns of behaviour institutionalized poverty in order remain relevance and to keep the poor youths to seek for whatever means including militant activities and terrorism as the last option to survive. Given the problems of unemployment, poverty, limited education and lack of opportunities for political participation, young people are more likely to be engaged in risky behaviours.

The political structure failed to pursue sustainable policies that ensures maximum exploitation of oil in line with laid down rules and regulation that will entrench transparency. It has been recognized and documented that one of the main reasons for the widespread and deep poverty in Nigeria is the lack of transparency and accountability.

\subsection{Democratic Deficit}

One of the observed challenges that continue to undermine political governance structure is democratic deficit. The inability of Nigeria to exercise effective and truly inclusive democracies remains a leading governance challenge in Nigeria (Andrew, 2003). When elections meet the global standards of fairness, administrative professionalism and respect for human rights, they provide formidable platform that support other sectors for greater efficiency.

\section{Ways of Strengthening Political Governance}

In the discussion on the challenges of political governance in Nigeria, it is found that poor leadership and weak institutions, inability of political structure to undertake effective checks and balances of the extractive industries, endemic corruptions, and failure to institutionalize the culture of transparency are amongst other intervening variables that endear ineffective and inefficient management of extractive industries in Nigeria. An evaluation of the strategy, process and practices by the Senate Committee report indicates that there are huge challenges to the realizing of the full benefit of revenue generated from crude oil.

The Senate observations revealed that, inadequate and lack of proper coordination between key agencies of government such as Ministry of Finance, Ministry of Petroleum Resources, Nigeria National Petroleum Corporation, Department of Petroleum Resources and Federal Inland Revenue Services created gap for mismanagement and 
misappropriation of the proceeds from crude oil sale. The uncoordinated and virtual absence of reconciliation on regular basis between sensitive institutions of government controlling the extractive industry encourages corrupt practices.

Today, NNPC still controls the revenue account of NPDC which undermines its status as a separate legal entity and makes proper accountability difficult. The ineptitude of the public office holders, and their nonchalant work attitude rendered effective management of extractive resources especially, crude oil, useless. There is no legal framework for revenue transparency in Nigeria. The absent of effective legal framework make way for NNPC pay their operational expenditure direct from Federation fund, without appropriation by the National Assembly, and continue to control the revenue account of NNPC that makes accountability and transparency more difficult. On the whole there is no due process and diligence in the operation of NNPC.

For effective political governance structure to ensure proper management of resources extracted, our electoral processes should emphasis the selection of public office holders through agreed rules and processes. This process will create the necessary foundation for the emergence of leaders that have credible and accepted mandates to govern (UNDP, 2009). In this way, strong institutions will emerged and transparency and accountability in all sectors guaranteed. In addition, transparency and accountability rests on effective implementation and strict adherence to rule of law. Rule of law in the sense of good governance encompasses supremacy of the constitution and dependable independent judiciary. This would normalize practices in all sectors of the nation. It will enhance transparent behaviour of service, commitment to the people's welfare, high sense of civility, with the formulation of policy that reflects the dynamics of socio-political and economic interests of the masses.

The problems of governance rest on lack of people's sovereignty. Power is not derived through the free and fair election that reflect the consent of the governed and perhaps revert to the citizens when abuse. The electorate votes (does not count and therefore, man of unproven and questionable integrity fund their way into power with complete neglect of values and norms that promote transparency and accountability

The civil society has enormous roles to ensure effective political governance in Nigeria. Civil society in an important element in this direction as they can ensure that a holistic, inclusive and need based approach is taken in enhancing political governance. They can offer support for good governance through promoting accountability in corporate governance.

\section{Conclusion and Recommendations}

Ineffective political governance structure has the danger of undermining development benefits associated with extractive industry, if there are no attempts to maximize political will to implement good framework and instruments to guarantee judicious use of the extractive resources proceed. The study therefore suggests that:

(i) The Government should honestly encourage Nigerian Extractive Industry Transparency Initiative to implement the NEITI Act of 2007.

(ii) The legislature should via oversight functions, evaluate without prejudice to any relevant contractual obligations and/or sovereign obligations, the practices of all extractive industries. In this way, they should monitor and ensure that all payments due to the federal government from all extractive industries including taxes, royalties, dividends, bonuses, penalties, levies are duly made.

(iii) Inter-agencies reconciliation meetings between sensitive economic institutions such as Ministry of Finance, Nigeria National Petroleum Corporation, Central Bank of Nigeria and Federal Inland Revenue Services should be done on regular basis so that revenue are properly and legally accounted for.

(iv) It is clear from the analysis that revenue transparency is lacking even as it is the key to improving governance. Loss of revenue is due to insufficient and inadequate multi-pronged approach to fighting corruption, an effective approach or strategy for fighting corruption largely depend on legislative framework for transparent and accountable government including free and fair election, budge law, fiscal responsibility law, political will and commitment to fight corruption. Corruption in the industry should not be tolerated for political reason.

(v) The National Assembly should expeditiously pass the Petroleum Industry Bill (PIB). The National Assembly to ensure checks and balances for due process in revenue practice.

\section{References}

Andrews, M. (2003). New Public Management and Democratic Participation: Complementary or Competing Behaviour in Journal of Public Administration, Vol 26 No. 8.

Brautigam, D. and Knack, S. (2004). Foreign aid, Institutions and governance in Sub-saharan Africa. Economic Development and 
Cultural Change, (Internet). Available from http://www.ssrnetwork.net/document Library (Access July 2014)

Clubba, M. (2009). Governance and Development. The Current role of theory, policy and practice. In World Economics, Vol. 10.

Hope, K. K. (2002). From Crisis to Renewal: Development Policy and Management in Africa. Leiden-Netherlands, Brisk Pub.

Kabbey, O. (2003). The Challenges of African Development. New York, Oxford University Press.

Kauzy, J. M. (2007). The human factorl in Global Governance: Leadership Capacity Development Perspective in Africa. United Nations Discussion Paper (internet) Available at www.infor.com

Nnaa, B. G. (2011). The Political Economy of Oil and Militancy in the Niger Delta. Implementations on Development in Nigeria (unpublished Ph.D Thesis) University of Calabar, Calabar, Nigeria

Nnaa, B. G. and Kia, B. (2013). Political Economy of Terrorism in Africa: The Nigerian Experience in Beko International Journal of Social and Economic Research, Special Edition, Vol. 5 No. 2.

Obadina, T. (2000). Africa's Crisis of governance. Africa Economic Analysis (Internet). Available from http://www.atbis.com (Accessed August, 2012).

Patrick, S. (2011). Time to bolster Africa's Security Institutions, CFR blog (internet). Available from http://blogs.cfr.org. (Accessed July 2014).

Sawyer, A. (2002). Violent Conflict and Governance Challenges in West Africa: the Case of the Mano River Basin Area. In Journal of Modern African Studies vol. 42 No. 3.

Sharma, S. D. (2007). Democracy, good governance and Economic Development. Taiwan Journal of Democracy vol. 2 No. 1.

UNDP (1997) Good governance and sustainable human Development. UNDP Policy document Available from http://minor.undp.org. (Accessed July 2014)

UNDP (2009). Elections and Conflict Prevention: A guide to Analysis, Planning and Programming. UNDP Publication. Available at www.infor.com. (Accessed July 2014).

Willard, T. (2009). Social Governance and Networking for sustainable development. International Institute for Sustainable Development (internet). Available on http://www.Lisd.org. (Accessed July 2014).

World Bank (2003). Reforming Public Institution and Strengthening governance: a World Bank Strategy: Implementation Update. Washington, DC, World Bank. 